\title{
The Commercial Application of Biosensors as an Analytical Device
}

\author{
Pavel Rout* and Chaitali Chakraborty
}

\author{
Department of Dairy Chemistry, F/O: Dairy Technology, WBUAFS, \\ Mohanpur Campus, Nadia 741252, West Bengal, India
}

*Corresponding author

\section{Keywords}

Biosensors, Bioluminescent, Opto-Electric, Piezoelectric, Microbiological, Reproducibility

\section{Article Info}

Accepted: 05 April 2020 Available Online: 10 May 2020

\section{A B S T R A C T}

Here various types of biosensors such as physicochemical, bioluminescent, electrochemical, opto-electric, piezoelectric, thermometric and magnetic has been deliberated to show their usefulness and applications in multiple field. Food industry requires suitable analytical methods for the safety and quality checking of foods. Chemical and biological hazards detection in foods is important to the human health. By on line measurement of different food components such as glucose, fructose, sucrose, lactose, lactic, malic, acetic, ascorbic, citric and amino acids, ethanol, glycerol, and triglyceride, polyphenols, oxygen, hydrogen peroxide, mycotoxin, vitamins, heavy metals, the food safety and microbiological quality aspects could be beneficial. Fluorescent biosensors have a large application in drug discovery and in cancer cell determination. Current and future researches may include a miniature array of biosensors, with rapid performance, high specificity, reproducibility and sensitivity.

\section{Introduction}

A biosensor is a measuring instrument that consists of biologically active molecules such as enzymes, antibiotics, phages, aptamers, or single-stranded DNA with a suitable physicochemical transducer. Bioluminescent, electrochemical, opto-electric, piezoelectric, thermometric and magnetic transducers are common types. There is an also immunochromatographic device, which does not use any of the transducers mentioned above. They have lateral flow strips which used in ultrasensitive tests for on-site visual detection of analytes. Mostly used commercial lateral flow strips are the home pregnancy strip and glucose testing strip.

Biosensors consist of a receptor, a transducer, an amplifier and a display monitor. A bioreceptor identifies the target analytic and a transducer converts the recognition event into a measurable electrical signal. A wide range of subjects from small protein to large 
pathogens can be detected by biosensors. An electrochemical biosensor is more appropriate for onsite analysis and they can easily be miniatured for handheld devices.

Biosensors have a potential market for commercial application in the area of medical science, food science, agriculture, veterinary services, microbial contamination and environmental biothreat.

\section{Component of biosensors}

\section{Receptors}

\section{Enzymes}

Enzymes are often used as biomaterials for the development of biosensors. These biosensors utilize enzymes (Table. 1) which are specific for the desired molecules and catalyze generation of the product, which is then directly determined using transducer.

Some factors are influence on the performance of enzyme-based biosensors, i.e. enzyme loading, suitable $\mathrm{pH}$, temperature and cofactors in some cases.

\section{Antibodies}

An antibody is a complex biomolecule. It consists of hundreds of individual amino acids arranged in an ordered sequence. An antigen-specific antibody fits its specific antigen in a unique way. This property of antibodies ismost important to their usefulness in immunological biosensors or immunosensors (J.M.Song and Vo-Dinh T2004).For non-fluorescent analyte systems, sensitivity increases with decreasing amounts of immobilized reagent (Tromberg et al., 1987). In microplates, tubes, capillaries or on glass strips are acoupled with some kind of electrochemical sensor and by this the common enzyme-linked solid phase immune assay (ELISA) is performed to measure the label generated signal (Skládal 1997). Cancer cells can be monitored by immunosensors (Ehrhart et al., 2008, Malhotra et al., 2010).

\section{Nucleic acids}

Biosensors gain their high sensitivity and selectivity on DNA, RNA and peptide nucleic acid from the very strong base pair affinity between nucleotide strands (Borgmann et al., 2011). Nowadays, as probe material mainly synthetic oligodeoxyribonucleotides (ODNs) are used in the DNA hybridization sensors. End-labels, such as thiols, disulfides, amines, or biotin, are incorporated to immobilize ODNs to transducer surfaces (Labuda et al., 2010). The complementarity of adeninethymine and cytosine-guanosine pairing in DNA forms the basis for the specificity of biorecognition in DNA biosensors (Vo-Dinh and Cullum 2000).

DNA biosensors were deeper reviewed for example by Drummond et al., (2003) or Sassolas et al., (2008). Different uses of DNA based biosensor are mentioned in Table 3 .

\section{Cells}

These kinds of bioreceptors are either based on biorecognition by an entire cell (Figure.1.) or a specific cellular component that can make a specific binding to certain species. The major advantage of this class of bioreceptors is that the detection limits can be very low because of signal amplification. Based on bioreceptors catalytic or pseudo catalytic properties many biosensors are developed (Vo-Dinh and Cullum 2000). For example, viable or non-viable microbial cells are utilized in case of microbial biosensors. Nonviable cells obtained after permeabilization and viable cells utilize the respiratory and metabolic functions of the cell; thus, the analyte may be monitored as a substrate or an 
inhibitor of these processes (D'Souza 2001). Cell-based biosensors (CBBs) may be applied to analyze the effect of pharmaceutical compound on a given physiological system (Xu et al., 2002).

Living cells can be treated as the primary biosensor, but there are some difficulties in the selection, the culture and the maintenance of living cells. The coupling of living cells and the secondary sensor are difficult (Wang et al., 2005).

\section{Transducers}

It is an analytical tool which provides an output quantity having a relationship to the input quantity (McNaught and Wilkinson 1997).Biosensors can be classified according the physiological properties and methodsthey utilize. Transducers can be differentiated in six main types: electrochemical, electrical, optical, piezoelectric (mass detection methods), thermal and bioluminescent.

\section{Electrochemical}

Electrochemical biosensors are based on monitoring electroactive species that are attached with the biological components (e.g., enzymes and cells). This kind of transduction can be performed under two broad methods: potentiometry and amperometry.

\section{Amperometric}

In Amperometric biosensors constant potential (D.C.) is applied. By using a potentiostat the constant potential is applied. This current is produced by the biological element and related to an electrochemical species. The electrochemical set-up frequently consists of a reference electrode Such as $\mathrm{Ag} / \mathrm{AgCl}$ and a working electrode such as gold, platinum, glassy carbon, graphite or carbon paste. The Table-4 shows various types of amperometric biosensors and their inventors.

Mostly used enzyme-based biosensors are the detection of glucose with glucose oxidase. These biosensors are better than the potentiometric ones; these are very sensitive and more suitable for mass production (Ghindilis et al., 1998).

\section{Potentiometric}

Under conditions of zero current flow, potentiometric biosensors are based on monitoring the potential of a system at a working electrode, with respect to an accurate reference electrode. A small change in the charge of the proteins is observed due to Antibody-antigen binding, that charge deference can be detected by this biosensor.

Ion selective electrodes (ISEs) areexample of this type of biosensors. The change in $\mathrm{pH}$ due to enzyme activity, can easily be monitored with a $\mathrm{pH}$ sensitive ISE. Table.5. shows types of potentiometric biosensors.

Estimating monophenolase activity in apple juice, determining the concentration of sucrose in soft drinks, measuring isocitrate concentrations in fruit juices, and determining urea levels in milk this type of biosensor used.

\section{Electrical}

\section{Conductometric (Impedimetric)}

The inverse value of resistance is called conductance and thus the name conductometric has been used. When ions or electrons are produced, the overall conductivity or resistivity of the solution is changing. Conductance measurements have relatively low sensitivity. The table- 6 shows various inventors along with their works on conductometric biosensors. 


\section{Ion-sensitive}

In earlier days, biosensors, which are based on Ion-Selective field-Effect Transistors (ISFETs) considered as a category of potentiometric sensor, but now, separated into the fourth class of electrochemical sensors (Thévenot et al., 1999), according to the last IUPAC technical report on electrochemical biosensors. These semiconductor FETs consists an ion sensitive surface. Electrical potential of that surface changes due to the interaction between ions and the semiconductor. Its developed version is called ENFET (Enzyme Field Effect Transistor) (Mohanty and Kougianos 2006). Enzyme biosensors based on ISFETs (Dzyadevych et al., 2006).

\section{Optical}

These sensors are based on measuring the illumination or to light emission. Optical biosensors can employ a number of techniques to detect a target analyte and are based on well-founded methods including chemiluminescence, light absorbance, fluorescence, phosphorescence, photothermal techniques, light polarization and rotation, surface plasmon resonance (SPR), and total internal reflectance. By measuring the intensity or decay time, these types of sensors are worked.

\section{Surface plasmon resonance (SPR)}

SPR occurs when light is reflected at the interface of a material with high refractive index and a material with low refractive index. Between these two layers, a thin layer of a good conductor such as gold or silver is required (Glaser, 2000) an evanescent wave developed at this interface can interact with electron packages in the conductive layer. A very specific energy is required to raise those surface plasmons.
The plasmon excitation energy can be measured with monochromatic light which is reflected at different angles. Deoxyribonucleic acid (DNA) binding or Antibody antigen interactions can be observed by SPR.

Commercially, one of the most popular optical-based biosensor systems supplied by BIAcore (Uppsala, Sweden). This instrument can be used to study a wide range of biological interactions, automatically and in real-time. The instrument is based on SPR. SPR sensors have been used extensively to investigate the presence of contaminating microorganisms in food and to determine food quality. For example, an optically based biosensor was recently used to screen poultry liver and eggs for the presence of the drug nicarbazin, a feed additive used to prevent outbreaks of coccidiosis in boiler chickens (B.D. Meshram et al., 2018).

Mohammed et al., have also demonstrated the use of this technique to detect the presence of allergens, in particular peanuts, during food production. Another study shows that E. coli and Salmonella could be detected in skim milk (limits of detection of 25 and 23 $\mathrm{CFU} / \mathrm{mL}$, respectively).

\section{Piezoelectric}

The piezoelectricity phenomenon is used in mass sensitive transducers (Luong and Guilbult, 1999).

If an oscillating current field is applied in a quartz disc with two deposited electrodes, an acoustic wave is generatedand that propagates through the crystal of the disc. The frequency dependent on the crystal properties (such as chemical structure, densityand the orientation the crystal is cut). The frequency is also influenced by mass deposited onto the crystal surface (or in many cases onto the electrode 
surface which is deposited on the crystal). This allows very sensitive detection of small mass changes on the crystal surface.

Principle wise mainly two waveforms are used. One of them is surface acoustic wave (SAW) device. High frequencies of 30-200 $\mathrm{MHz}$ give the crystal a very good theoretical sensitivity, but due to practical difficulties biosensors are mainly based on bulk acoustic wave (BAW) devices (Leonard et al., 2003).

\section{Thermometric}

Thermometric biosensors measure the change in temperature which occurs due to heat fluctuation that occurs during biochemical reactions. Highly sensitive thermistors are used to monitor the change in temperature. Most biological reactions are exothermic, some of them are endothermic. In enzymatic reactions the change in enthalpy is $20100 \mathrm{~kJ} / \mathrm{mol}$.

Measurements can be developed by coimmobilizing enzymes for signal amplification or by using high-protonation enthalpy buffers such as TRIS (Giese, 2002).

\section{Immobilization}

The immobilization of the biological element on the transducer is very important for the biosensor performance. The biomolecule immobilized on the surface of a transducer, and retained with its full activity and longterm stability regarding its function and immobilization. By the immobilization step, the transducer should be unaffected. Many immobilization methods also have some disadvantages. Therefore, the immobilization method must be chosen and adapted for the particular bio element, transducer, matrix and other assay requirements (Kuhnert et al., 2000).
The most common immobilization methods used for biosensors can be divided into physical and chemical methods. Physical methods include adsorption, entrapment, encapsulation and confining. Chemical methods are cross-linking and covalent immobilization. However, cross-linking of biomolecule is carried out to improve the stability of physical methods (Leonard et al., 2003).

\section{Applications of biosensors in food industries}

Food industry requires suitable analytical methods for the safety and quality checking of foods. Chemical and biological hazards detection in foods is important to the human health. Also, sugars, alcohols, amino acids, flavours, sweeteners analysis can be done by using biosensors. In food sector the uses of biosensors mainly focus on analysis of food composition and detection of allergens, toxins, pathogens, additives etc. In food and fermentation process, quick, cheap, and safe analytical processes are generally required to measure sugar (glucose, sucrose, lactose and fructose) content.

There are many scientific publications on biosensor but very few biosensors are commercially available in market. There are few commercial biosensors used in food industry are shown in Table 7.

\section{Biosensors in food quality}

Now a days many batch operations in the food industry are being replaced by automated continuous processing. Accordingly, there is an increasing demand for instruments suitable for automatic in line quality control and at the end of the line so that the real time state of the process can be described. 
This will increase the food safety and also provide less effective control, less employment, time and energy saving (Velasco-Garcia and Mottram, 2003).

These also can be used as analytical tools in some food industries, especially applied to the determination of the composition, degree of contamination of raw materials and processed foods, and for the on-line control of the fermentation process.

Enzymatic biosensor based on cobalt phthalocyanine has a good capability to monitor the ageing of beer during storage (Ghasemi-Varnamkhasti et al., 2012).

\section{Ethanol Biosensor}

To monitor ethanol production, the combination of alcohol dehydrogenase $(\mathrm{ADH})$ and alcohol oxidase (AO) is used with an oxygen electrode. A second dehydrogenase enzyme linked to the $\mathrm{ADH}$ and $\mathrm{AO}$ system allows the determination of many other dehydrogenases and their substrates. Provesta Corporation (Bartlesville, OK) has inovated the Multipurpose Bioanalyzer, by using this concept. Depending on the enzyme systems the Bioanalyzer can detect more than 100 biochemical and chemical substances. ISFET is also used for ethanol determination.

To determine ethanol concentration in alcoholic beverages microbial biosensors were can be used. Generally, dilutions between 40 and 500 times were performed. Results were compared with the enzymatic spectrometric method. The correlation coefficient of those experimental values is 0.9983 shows a good correlation between biosensor and spectrometric method (B.D. Meshram. et al., 2018)

The biosensor consists of immobilized cells (yeast or bacteria), a gas permeable membrane (Teflon) and an oxygen electrode. Porous membranes retaining the microbial cells, but those cells are fixed on the surface of the electrode's outer teflon membrane. Thus, the cells are trapped between the two membranes. A gas permeable membrane is placed on the surface of electrode and covered with nylon net. These membranes are attached by rubber-O-rings. The steady state current obtained depend on the concentration of ethanol/methanol. The response time is 10 min at $30^{\circ} \mathrm{C}$ (Rajasekhar et al., 2005).

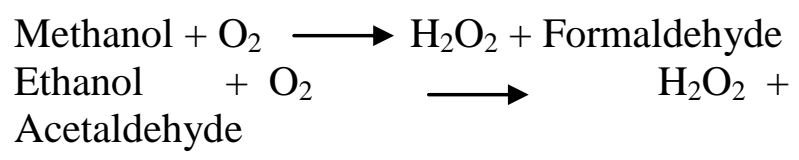

\section{Monitoring of wine quality}

Wine is a complex mixture of various compounds, at different concentrations, present simultaneously. The compounds are water, ethanol, glycerol, sugars, organic acids and various ions. Ethanol and glycerol have a higher concentration, other aliphatic and aromatic alcohols, amino acids and phenolic compounds are in fewer concentrations.

Newly three different PQQ-dehydrogenases [glucose dehydrogenase (GDH), alcohol dehydrogenase (ADH), and glycerol dehydrogenase (GIDH)] are isolated and purified from Gluconobactersppor Erwiniaspp. have been used for determination of main compounds of wine.

The main enzyme substrate (glucose for GDH, glycerol for GIDH and ethanol for $\mathrm{ADH})$ is firstly oxidized while the enzymes cofactor is simultaneously reduced. The active form of the enzyme is regenerated via the interaction with the electrochemical mediator (modified redox polymer), which is maintained in its oxidized form by the positive potential applied at the electrode. 


\section{Antioxidants and free radicals}

Antioxidants are one of the main ingredients that protect food attributes by preventing oxidation that occurs during processing, distribution and end preparation of food. Amperometric biosensors are generally used for the determination of antioxidants in various food (Mello and Kubota, 2007).

\section{Tea biosensor}

In case of determining quality of black and green tea polyphenols play a crucial role.The polyphenol contents affect the Major quality attributes such as colour and astringency. Therefore, it is necessary to know quantity of polyphenols in tea. Also, tea polyphenols also have a strong antioxidant property which improves the nutrition and health of human bodies. In this context CFTRI, Mysore developed an enzyme based amperometric biosensor (Fig. 2) for the quantification of total polyphenol content in tea infusions. Both lab and industry trials were successfully observed for tea polyphenols detection and tea biosensor technology (Sujith Kumar et al., 2011).

\section{Fermented food seasoning sensor}

For food and fermentation industry applications, glutamate oxidase can be immobilized and used in conjunction with an electrochemical device to determine Lglutamic acid, which is fermented for use as a food seasoning. Glutamate oxidase catalyses the oxidation of glutamate with the consumption of oxygen. This allows for the use of an oxygen probe as the transducer for the glutamate sensor.

\section{Determination of ascorbic acid in fruit juices}

Flow injection Potentiometric system is improved for continuous determination of ascorbic acid and other parameters. The oxygen consumption is detected by the electrode. Oxygen consumption rate is proportional to the ascorbic acid amount of the sample (Ashkenazi et al., 2000).

\section{Plant tissue biosensors}

To form a biocatalytic sensor, the use of plant tissue in conjunction with electrochemical elements is inexpensive, simply constructed and requires few co-factors and also an alternative to enzyme and microbial electrodes. Plant tissue biosensors can be particularly selective if the substrate to be determined is either a major nutrient or a functional metabolite of the enzymecontaining tissue (biocatalyst). An example of such a biosensor is the banana electrode shown in Figure 3.

Ascorbic acid is measured by using a probe,depend on the catalytic reaction of ascorbic acid oxidase (mainly present in cucumber peel, cabbage, zucchini, and yellow squash). Using sugar beet tissue fixed to an electrode measure the amount of Tyrosine within 5 to $10 \mathrm{~min}$. Cysteine carbon-sulphur lyases catalyse (present in garlic, onion, cabbage, broccoli, cauliflower, and mushrooms) rapid enzymatic reactions which initiate flavour and colour producing chemical processes and can be used for sulfoxide sensors.

Dialysis membranes can fix chopped cabbage to an ammonia gas-sensing electrode, which is creating a selective, though not overly sensitive, detector for S-methyl-L-cysteine sulfoxide. Commercially available gassensing electrochemical probes have been combined with tissues; squash sensors determine glutamic acid; cucumber leaves are used to detect L-cysteine and corn-based sensors detect pyruvate. 


\section{Fish freshness analysis}

Fish freshness has been examined chemically and expressed as $\mathrm{K}$-value which is useful index of raw fish freshness. The $\mathrm{K}$ - value consists the sample preparation and the complex sensor system with various kinds of biochemical substances because the K-value is calculated from the concentrations of hypoxanthine $(\mathrm{Hx})$, inosine $(\mathrm{HxR})$, inosine 5monophosphate (IMP) and in the fish-extract solution. Also, various biochemical process reagents are used. Then, a new method is required at restaurants, kitchens and fish markets, i.e., non-destructive methods with simple biochemical reaction, such as smell evaluation of bad fish-odour with human smell sense (Mitsubayashi et al., 2004).

Trimethylamine (TMA) is common substance in sea-food, and it is produced due to decomposition of trimethylamine $\mathrm{N}$-oxide (TMAO) in sea animas. The fresh marine products contain little TMA. Mitsubayashi et al., (2004) constructed a TMA biosensor by immobilizing flavin containing mono oxygenase type 3 (FMO3) and contain a dissolved oxygen electrode. With flow injection analysis (FIA) this sensor is calibrated against TMA solutions. It was obvious that the TMA sensor with FMO3 would be most useful for evaluating fishfreshness (Coefficient of variation4.39\%, $\mathrm{n}=5$ ) (B.D. Meshram. et al., 2018).

\section{Quality control of meat}

For quality control of meat, meat check and bio check sensors are used commercially. A four-electrode array attached to a knife in the meat check, which can be inserted into meat to analyse the glucose gradient immediately below the surface. The gradient informs the microbial activity on the surface, which is an indicator of meat quality. The device shows results in seconds where laboratory-based microbiological test takes days. The bio checks method transformed the glucose sensor into a device, which helps in detecting and analysing microorganisms present in aqueous solutions. From the respiratory pathways of microorganisms, the system transfers electrons and it takes less than two minutes.

The lactic acid concentration indicates the pre -mortem metabolic activity, physical stress and deficiency in the meat quality. Enzymatic biosensor based on immobilized lactate oxidase as bioreceptor and an amperometric transducer (Bergann et al., 1999). This biosensor estimates lactic acid very quickly and at low cost and does not needs sample preparation.

\section{Biosensors for the detection of microorganisms}

Microorganisms produce current when they to the contact of an electrode, so an electrochemical method can be used to detect microbial loads. In 1979, a two electrodes system (a determination electrode and a reference electrode) is used to measure microbial populations and this having a 15 min response time. Each electrode consists a silver peroxide cathode and a platinum anode. The anode of the reference electrode was covered with a cellulose dialysis membrane, which prevent penetration of microorganisms.

On the surface of the anode the microorganisms were oxidized and a current was produced. Current differences were proportional to the number of cells of Saccharomyces cerevisiae and Lactobacillus fermentum. By using an electrochemical system Bacillus subtilis populations can be continuously monitored in a fermenter. Nishikawa et al., constructed a fuel cell-type electrode system to detect load of microorganism in polluted water, but it can 
probably be used to rapidly (10-20 min) assay wash water in food processing plants. The current generated varies between different microorganisms but, at equivalent cell concentrations > 104 cells $/ \mathrm{ml}$, a linear relationship is obtained between the current at the electrode and plate count data.

The Cranfield Institute of Technology has developed a biosensor for the rapid detection of cells in a variety of water-based fluids. This device, Biocheck, is portable, hand-held, battery-operated, robust, and easily operated. The lowest contamination level detected in Biocheck is approximately $2 \times 106$ organisms $/ \mathrm{ml}$.

\section{Biosensors in dairy industry}

\section{Online monitoring of milk}

The increasing demand for on-line monitoring of milk quality directs the industry to look for practical solutions, and biosensors could help in this.

However, biological research is needed to determine how sensor derived information can be used to improve the product quality (table.8) other than by separating the milk into sources of high and low quality (B.D. Meshram. et al., 2018).

\section{Biosensor for quality control in milk}

The food industry requires suitable analytical method for quality control, methods must be reliable, specific, rapid and cost effective. The study was carried out to measure the recent problem, the analysis of the presence of urea in milk, called "synthetic milk". This urea biosensor is immobilized urease enzyme with the ammonium ion selectively electrode of a potentiometric transducer. However, it is worth the mentioned that since milk is a complex system it contains much interference, which makes conventional methods less reliable (Verma and Singh, 2003).

\section{On- line determination of lactose concentration in milk}

Online determination of lactose content of milkis generally measured by the cascade enzyme biosensor. The enzyme galactosidase (GAL) makes a cleavage in the disaccharide lactose and produces glucose and galactose. The glucose reacts with glucose oxidase (GOD) to produce $\mathrm{H}_{2} \mathrm{O}_{2}$. Horseradish peroxidase (POD) oxidizes $\mathrm{H}_{2} \mathrm{O}_{2}$ in presence of 5-ASA (amino-salicylic acid) as a mediator. The oxidized form of the mediator is reduced at the electrode resulting in an amperometric signal proportional to the lactose concentration (Ferreira et al., 2003).

\section{Milk urea biosensor}

Animal feed protein supplements are highly expensive. The conversion of feed protein into milk protein is observed here. Excessive levels of nitrogen derived from feed may increase the urea concentration of milk, without increase in milk production. This high concentration of urea may impair reproductive functions and also causes excess nitrogen in dairy waste which is harmful for environment. The normal range of milk urea nitrogen (MUN) data is $5-20 \mathrm{mg} / \mathrm{dl}$.

\section{Biosensor for lactic acid}

Among the organic acids present in food, glutamic acid, lactic acid and ascorbic acid are important. On the acidity of the curd the quality of mozzarella cheese strongly depends. Biosensor has been used to measure the lactic acid, to control the acid development. The system consists of an electrochemical (flow-through flow-jet) cell assembled + connected to an amperemeter 
with platinum sensor covered with the immobilized lactate oxidase.

Lactate $+\mathrm{O}_{2} \longrightarrow$ Pyruvate $+\mathrm{H}_{2} \mathrm{O}_{2}$

$\mathrm{H}_{2} \mathrm{O}_{2}$ probe is used to detect the amount of lactate in the curd. The real time analysis of lactate helps to control of the curd ripening at different pasteurization temperature. This method is more sensitive than $\mathrm{pH}$ probe
(Rajasekhar et al., 2005). A biosensor, based on screen printed carbon electrode, was integrated into flow cell. And enzymes were immobilized on electrode by engulfment in a photo cross linkable polymer. The automated flow-based biosensor could quantify the tree organophosphate pesticides in milk. (Mishra et al., 2014).

Table.1 List of different analytes with corresponding receptor enzymes along with references

\begin{tabular}{|c|c|c|}
\hline Enzymes & Analytes & References \\
\hline $\begin{array}{l}\text { Glucose Oxidase, } \\
\text { Glucose Dehydrogenase }\end{array}$ & Glucose & Monošík et al., 2012 \\
\hline Oxidoreductase & Lactate & $\begin{array}{l}\text { Huang et al., 2008, } \\
\text { Katrlík et al., 1999, } \\
\text { Pereira et al., } 2007\end{array}$ \\
\hline Oxidoreductase & Malate & $\begin{array}{l}\text { Arif et al., 2002, } \\
\text { Monošíketal.2012, Prodromidis et al., 1996, } \\
\text { Wang et al., } 2008\end{array}$ \\
\hline Oxidoreductase & Ascorbate & $\begin{array}{l}\text { Vermeir et al., 2007, } \\
\text { Wang et al., 2008), }\end{array}$ \\
\hline Oxidoreductase & Amino Acids & $\begin{array}{l}\text { Pollegioni et al., } 2007 \text {, } \\
\text { Sacchi et al., } 1998\end{array}$ \\
\hline Oxidoreductase & Alcohol & $\begin{array}{l}\text { Katrlík et al., 1998, } \\
\text { Pena et al., 2002, } \\
\text { Smutok et al., 2006, } \\
\text { Tkáč et al., } 2003\end{array}$ \\
\hline Oxidoreductase & Cholesterol & $\begin{array}{l}\text { Lia and Gub 2006, } \\
\text { Umar et al., 2009, } \\
\text { Vidal et al., } 2004\end{array}$ \\
\hline Oxidoreductase & Glycerol & $\begin{array}{l}\text { Alvarez-Gonzalez et al., 2000, Monošík et } \\
\text { al., 2012, Niculescu et al., } 2003\end{array}$ \\
\hline Oxidoreductase & Fructose & $\begin{array}{l}\text { Tkáč et al., 2001, } \\
\text { Tkáč et al., 2002), }\end{array}$ \\
\hline Transferase & Acetic Acid & $\begin{array}{l}\text { Mieliauskiene et al., 2006, Mizutani et al., } \\
2003\end{array}$ \\
\hline Hydrolase & sucrose & $\begin{array}{l}\text { Soldatkin et al., 2008, Surareungchai et al., } \\
1999\end{array}$ \\
\hline Lyase & citric acid & Maines et al., 2000, Prodromidis et al., 1997 \\
\hline Ligase & DNA point mutation & Pang et al., 2006 \\
\hline Isomerase & 19-norandrostenedione & Sheu et al., 2008 \\
\hline
\end{tabular}

Source: Rastislav Monošíka, Miroslav Stred'anskýb, Ernest Šturdíka.Biosensors - classification, characterization and new trends, 2012 
Table.2 List compound discovered for using in DNA immobilization with references

\begin{tabular}{|l|l|l|}
\hline Occurrence & Compounds & Reference \\
\hline DNA immobilization & carbon paste & Girousi et al., 2004 \\
& pyrolytic graphite & Chen et al., 2000 \\
& glassy carbon & Pedano et al., 2003 \\
& carbon fiber & Tian et al., 2005 \\
& carbon nanotubes & Mani et al., 2009, \\
& & Niu et al., 2008 \\
\hline
\end{tabular}

Sources: Monošík R. et al., Biosensors - classification, characterization and new trends, 2012

Table.3 Applications of DNA based biosensors with references

\begin{tabular}{|l|l|}
\hline Application & Reference and Source \\
\hline $\begin{array}{l}\text { Determination of drug in blood serum } \\
\text { matrix }\end{array}$ & Vaníčková et al., 2005 \\
\hline $\begin{array}{l}\text { Detection of the DNA damage and } \\
\text { antioxidants protecting DNA from its } \\
\text { damage }\end{array}$ & $\begin{array}{l}\text { Bučková } \text { et al., 2002; Galandová } \text { et al., 2009; } \\
\text { Labuda } \text { et al., 2009; Vyskočil } \text { et al., 2010 }\end{array}$ \\
\hline $\begin{array}{l}\text { Voltammetric determination of 1- } \\
\text { aminopyrene and 1-hydroxypyrene }\end{array}$ & Ferancová et al., 2005 \\
\hline $\begin{array}{l}\text { For detection of the effect of berberine on } \\
\text { DNA from cancer cells }\end{array}$ & Ovádeková et al., 2006 \\
\hline
\end{tabular}

Source: Fojta, Electrochemistry of Nucleic Acids and Proteins - Towards Electrochemical Sensors for Genomics and Proteomics, 2005

Table.4 The working principle of various types of amperometric biosensor and their inventors

\begin{tabular}{|l|l|}
\hline Working principle & Inventor \\
\hline $\begin{array}{l}\text { Enzyme-catalysed electro-oxidation or electro-reduction, or their } \\
\text { enzyme-catalysed hydrolysis }\end{array}$ & Heller 1996 \\
\hline $\begin{array}{l}\text { Electron transfer or enzymes with a direct electron transfer from } \\
\text { the active Centre to the electrode (consumption of } \mathbf{O}_{2} \text { and } \\
\text { production of } \mathbf{H}_{2} \mathbf{O}_{2} \text { ) }\end{array}$ & Glaser, 2000 \\
\hline
\end{tabular}

Source: Subramanian Viswanathan, Hanna Radecka, Jerzy Radecki. Electrochemical biosensors for food analysis. 2009.

Table.5 Types of potentiometric biosensor

\begin{tabular}{|l|l|}
\hline Types & Inventors \\
\hline Ion Selective Electrodes (Ise) & Guilbault and Montalvo, 1969 \\
\hline Field Effect Transistor (FET) & Mello and Kubota, 2007 \\
\hline
\end{tabular}

Source: Sources: Monošík R. et al., Biosensors - classification, characterization and new trends. 2012 
Table.6 Inventors of various conductometric biosensor

\begin{tabular}{|l|l|}
\hline Works and contributions & Inventors \\
\hline $\begin{array}{l}\text { Impedance biosensor is used as commonly } \\
\text { a functional part of the Wheatstone bridge }\end{array}$ & Pohanka and Skládal 2008 \\
\hline $\begin{array}{l}\text { Double layer charging and concentration } \\
\text { polarization invented }\end{array}$ & Mohanty and Kougianos 2006 \\
\hline $\begin{array}{l}\text { Impedimetric biosensors were reviewed } \\
\text { and modified }\end{array}$ & Guan et al., 2004 \\
\hline $\begin{array}{l}\text { Use conductometric biosensors for } \\
\text { biosecurity }\end{array}$ & Muhammad-Tahir and Alocilja 2003 \\
\hline
\end{tabular}

Source: Subramanian Viswanathan, Hanna Radecka, Jerzy Radecki; Electrochemical biosensors for food analysis. 2009

Table.7 Commercial Food biosensors and corresponding companies

\begin{tabular}{|l|l|}
\hline Company & Biosensors \\
\hline Chemel AB & Glucose, lactose, saccharose, ethanol \\
\hline Gwent sensors & Glucose \\
\hline Analox Instruments & Ethanol, Methanol, Lactate, Glycerol \\
\hline BIAcore AB & Water soluble vitamins, Mycotoxins \\
\hline Texas Instruments & Peanut allergens, Antibiotics \\
\hline Universal sensors & $\begin{array}{l}\text { Ethanol, Methanol, Glucose, Sucrose, Glutamine, } \\
\text { Ascorbic Acid }\end{array}$ \\
\hline Research International & Protein, toxins, virus, spores and fungi \\
\hline Biomerieux & Microorganism \\
\hline Motorola & Microorganism and genetically modified organism \\
\hline IVA Co, Itd & Heavy metals \\
\hline The Answer 8000 & Sucrose, L-Glutamate, Alcohol \\
\hline Oriental electric & Fish deterioration tracking \\
\hline FAIZA 110-P & Glucose, Galactose, Lactate, L-Glutamate \\
\hline
\end{tabular}

Source: B.D. Meshram1, A.K. Agrawal, Shaikh Adil1, SuvartanRanvir and K.K. Sande; Biosensor and its Application in Food and Dairy Industry: A Review, 2018

Table. 8 Various developer and their on line determination of milk constituents

\begin{tabular}{|l|l|}
\hline Developer & Application \\
\hline Ashkenazi et al., 2000 & $\begin{array}{l}\text { Multi-enzymatic amperometric biosensor for } \\
\text { lactose in fresh raw milk }\end{array}$ \\
\hline Velasco- Garcia and Mottram, 2003 & Determine fat in milk \\
\hline Schmidt et al., 1999 & Free fatty acids detection \\
\hline
\end{tabular}

Source: B.D. Meshram1, A.K. Agrawal, Shaikh Adil, SuvartanRanvir and K.K. Sande;Biosensor and its Application in Food and Dairy Industry: A Review. 2018 


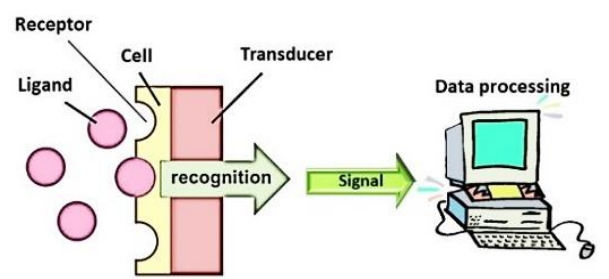

Figure.1 A cell based bioreceptor attached with the target analytes and through transducer the signal passes through towards data processing unit

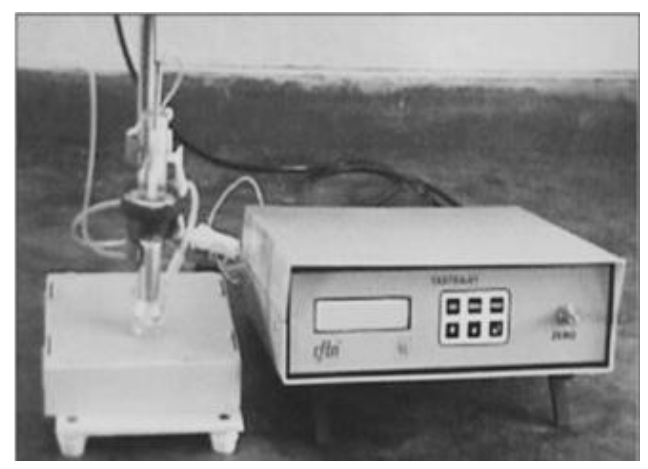

Fig.2 Tea biosensor designed and developed in CFTRI, Mysore

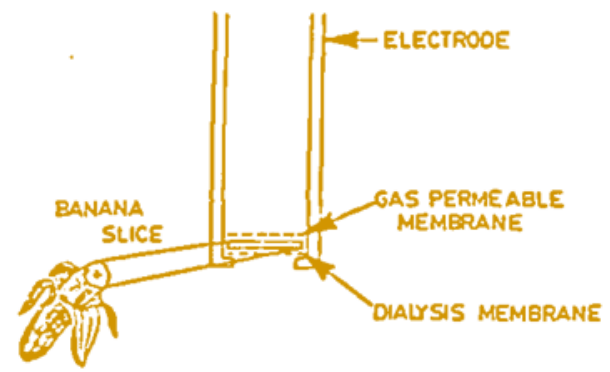

Figure.3 Schematic diagram of banana tissue electrode. Source: Sidwell and Rechnitz, 1986

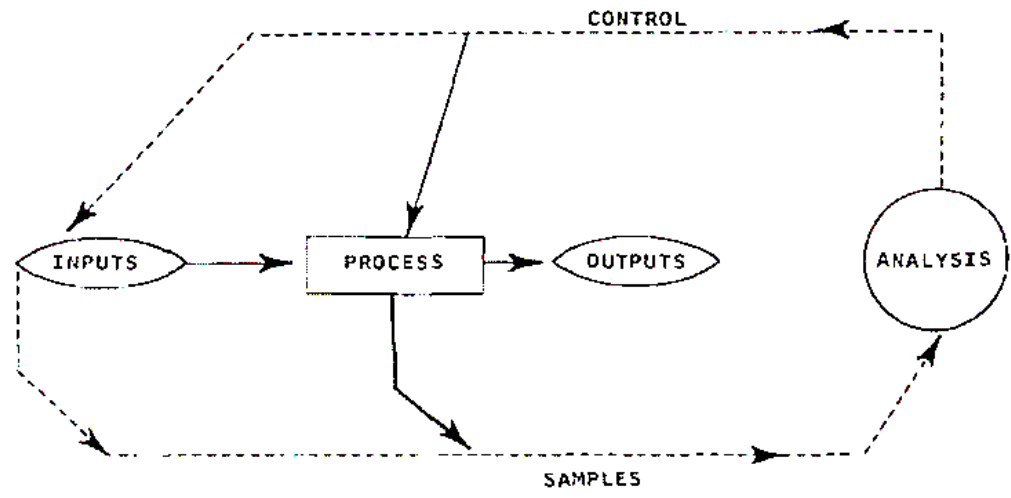

Figure.4 Desired feedback control of a process. Adopted from McMurdo and Whyard, 1984 


\section{Advantages of biosensors}

Rapid and continuous monitoring could help the food processor both reduce wastage from poorly controlled processes and increase productivity. This will increase microbial safety and also a more cost-effective control of food processing. The data generated should be used for process control as shown in Figure 3.

The first advantage of biosensors is its rapid action. Results came out in minutes rather than days. Second, biosensors do not require a large amount of sample preparation; their specificity allows direct measurement of particular analytes. A biosensor can be used by unskilled personnel. Another advantage is versatility. The biosensors being developed range from small, inexpensive, hand-held devices, for continuous, on-line monitoring of various food and industrial processes.

\section{Future scope}

In the manufacturing processes of beer, wine, bread, and some dairy products the microbial growth must be kept within certain limits. For regulate both the component and microbial levels of these Biosensors could be used.

Multifunctional and versatile analytes (like raw materials, trace compounds, sugars, alcohols, amino acids, vitamins, flavour additives, and contaminants, e.g. antibiotics, microorganisms and their enzymes, toxins etc.) sensing system is needed in one device and that must be easy to handle that without any skilled professional we can use that in practical area.

Without compromising specificity, sensitivity and workability a small sized in hand device is required. Biosensor is a good area of investing funds for using nanotechnology and nanobiotechnology.

\section{References}

Adam Heller, IoanisKatakis, Ling Ye; Biosensor including chemically modified enzymes. 1997. Volume 15, Number 2. Pages 390.

Alvarez-Gonzalez MI, Saidman SB, Lobo-Castanon MJ, MirandaOrdieres AJ, Tunon-Blanco P. Electrocatalytic Detection of NADH and Glycerol by NAD ${ }^{+}$-Modified Carbon Electrodes. Anal Chem. 2000.Volume 72. page520.

Andrey L. Ghindilis, ${ }^{*}$ PlamenAtanasov, ${ }^{*}$ Michael Wilkins, 'Ebtisam Wilkins. Immunosensors: electrochemical sensing and other engineering approaches. Biosensors and Bioelectronics. Volume 13, Issue 1, 1 January 1998, Pages 113131.

Arif M, Setford SJ, Burton KS, Tothill IE L-Malic acid biosensor for field-based evaluation of apple, potato and tomato horticultural produce. Analyst. 2002. Volume 127, page- 104.

Audrey Sassolas, Béatrice D. Leca-Bouvier, Loïc J. Blum. DNA Biosensors and Microarrays. Chem. Rev. December 21, 2007. Volume 108, Issue 1. Pages 109-139.

Bruce J. Tromberg, Michael J. Sepaniak, Tuan. VoDinh, Guy D. Griffin. Fiber-optic chemical sensors for competitive binding fluoroimmunoassay. Analytica Chemica. April 15, 1987. Volume 59, issue 8, Pages 1226-1230.

C.K. O'Sullivan, R. Vaughan \&G.G. Guilbault. Piezoelectric Immunosensors - Theory and Applications. Analytical letters. 27 Feb 2008.Pages 2353-2377.

Chaubey A, Malhotra BD. Application of conducting polymers to biosensors. Biosensors and Bioelectronics. Volume 17, Issue 5, May 2002, Pages 345-359.

Ferancováa $^{\mathrm{a}}$ M. Buckováa ${ }^{\mathrm{a}}$ E. Korgováa ${ }^{\mathrm{a}}$ O. Korbut ${ }^{\mathrm{b}}$, P. Gründler ${ }^{\mathrm{b}}$, I. Wärnmark ${ }^{\mathrm{c}}$, R. Štepán ${ }^{\mathrm{d}}$, J. Barek $^{\mathrm{d}}$, J. Zima ${ }^{\mathrm{d}}$, J. Labuda. Association interaction and voltammetric determination of 1-aminopyrene and 1-hydroxypyrene at cyclodextrin and DNA based electrochemical sensors.Bioelectrochemistry. October 2005. Volume 67, Issue 2, Pages 191-197.

George G. Guilbault, Joseph G. Montalvo Jr.Ureaspecific enzyme electrode. J. Am. Chem. Soc. April 1,1969. Volume 91, Issue 8. Page 2164-2165.

Glaser R. W., Surface Plasmon Resonance Biosensors and their applications, Kiuwer Academic/Plenum Publishers, New York.pp. 
2000.Pages 195-212

H. Mcmurdo, S. Whyard. Suitability of rapid microbiological methods for the hygienic management of spray drier plant. International journal of dairy technology. January 1984. Volume 37, Issue 1.

J. Labuda, K. K. Bubnicova, L. Kovalova, M. Vanickova, J. Mattusch and R. Wennrich. Voltammetric Detection of Damage to DNA by Arsenic Compounds at a DNA Biosensor. Sensors. 2005. Volume 5. Pages 411-423.

Jan Labuda, Ana Maria Oliveira Brett, Gennady Evtugyn, Miroslav Fojta, Marco Mascini, Mehmet Ozsoz, Ilaria Palchetti, Emil Paleček. Electrochemical nucleic acid-based biosensors: Concepts, terms, and methodology (IUPAC Technical Report). The Scientific Journal of IUPAC. 20, April 2010. Vol 82, Issue 5.

JiansheHuang ${ }^{\mathrm{a}}$ Yang Liu ${ }^{\mathrm{a} H a o q i n g H o u}{ }^{\mathrm{b}}$ TianyanYou $^{\mathrm{a}}$. Simultaneous electrochemical determination of dopamine, uric acid and ascorbic acid using palladium nanoparticle-loaded carbon nanofibers modified electrode.Biosensors and BioelectronicsDecember 2008, Volume 24. Issue 4. Pages 632-637.

Joon Myong Song, Tuan Vo-Dinh.Miniature biochip system for detection of Escherichia coli $\mathrm{O} 157: \mathrm{H} 7$ based on antibody-immobilized capillary reactors and enzyme-linked immunosorbent assay. Analytica Chemica Acta. 1 April 2004.Volume 507, Issue 1. Pages 115-121.

Joseph Wang. Carbon- Nanotube Based Electrochemical Biosensors: A Review; Electroanalysis. 18 January 2005; Volume17, Issue1. Pages 7-14.

Kang Xu, Shengshui Zhang, Bruce A. Poese and T. Richard Jow Lithium Bis (oxalato) borate Stabilizes Graphite Anode in Propylene Carbonate. The Electrochemical Society. 10 September 2002. Volume 5, Number 11.

Katrlik J, Pizzariello A, Mastihuba V, Svorc J, Stredansky M, Miertus S. 1999. Biosensors for L-malate and L-lactate based on solid binding matrix. Anal Chim Acta. Volume-379. Page- 193

Katrlik J, Svorc J, Stredansky M, Miertus S. Composite alcohol biosensors based on solid binding matrix.BiosensBioelectron. 1998. volume13. Page- 181-187

Kohji Mitsubayashi ${ }^{\mathrm{a}}$, YoheiKubotera ${ }^{\mathrm{b}}$, Kazuhisa Yano $^{\mathrm{b}}$, Yuki Hashimoto ${ }^{\mathrm{b}}$, TakuoKon ${ }^{\mathrm{b}}$, Shinya
Nakakura $^{\mathrm{b}}$, YoshitakeNishi ${ }^{\mathrm{c}}$, Hideaki Endo. Trimethylamine biosensor with flavincontaining monooxygenase type 3 (FMO3) for fish-freshness analysis. Sensors and Actuators B: Chemical. 29 September 2004. Volume 103, Issues 1-2, Pages 463-467.

Lubbers, DW, Optiz, N. The pCo2- /pO2optode: a new probe for measurement of $\mathrm{pCo} 2$ or $\mathrm{pO}$ in fluids and gases. Z Res Nat C. 1975; 30:532533.

M.I.ProdromidisC.D.StalikasS.M.Tzouwara-

KarayanniM.I.Karayannis.Determination of glycerol in alcoholic beverages using packed bed reactors with immobilized glycerol dehydrogenase and an amperometric FIA system. Talanta. January 1996.Volume 43, Issue 1. Pages 27-33.

M.L. Pedano and G.A. Rivas. Immobilization of DNA on glassy carbon electrodes for the development of affinity biosensors. Biosensors and Bioelectronics. March 2003. Volume 18, Issues 2-3,Pages 269-277.

MahdiGhasemi- Varnamkhasti $^{\text {ab }}$, María Luz Rodríguez-Méndez ${ }^{\mathrm{a}}, \quad$ SeyedSaeidMohtasebi ${ }^{\mathrm{b}}$, Constantin Apetreic ${ }^{\mathrm{c}}$, Jesus Lozano ${ }^{\text {ad }}$, HojatAhmadi ${ }^{\mathrm{b}}$, SeyedHadiRazavi ${ }^{\mathrm{e}}$, Jose Antonio de Saja ${ }^{\mathrm{f}}$. Monitoring the aging of beers using a bioelectronic tongue. Food Control.May 2012. Volume 25, Issue 1, Pages 216-224.

Maria N.Velasco-Garcia, Toby Mottram. Biosensor Technology addressing Agricultural Problems; Biosystems Engineering. January 2003. Volume 84, Issue 1, Pages 1-12

McNaught, A.D. (comp.) International Union of Pure and Applied Chemistry. 1997

Meshram, B.D., A.K. Agrawal, Shaikh Adil, SuvartanRanvir and Sande, K.K. 2018. Biosensor and its Application in Food and Dairy Industry: A Review. Int.J.Curr.Microbiol.App.Sci. Volume 7, Issue 02. Pages 3305-3324.

Mieliauskiene R, Nistor M, Laurinavicius V, Csoregi E. Amperometric determination of acetate with a tri-enzyme based sensor.Sensors and Actuators B: Chemical. 2006. Volume 113, Issue 2, 27 February 2006, Pages 671-676.

Minhong Yan, Scot A. Marsters, Iqbal S. Grewal, Hua Wang, Avi Ashkenazi and Vishva M. Dixit. Identification of a receptor for BLVS demonstrates a crucial role in humoral immunity. Nature Immunology. 2000. volume 1, pages37-41.

Minni Singh ${ }^{1}$, Neelam Verma, Arun Kumar Garg, 
NihaRedhu. Urea biosensors. Sensors and Actuators B: Chemical. 28 August 2008. Volume 134, Issue 1, Pages 345-351

Miriam Buckova, Jan Labuda, JozefSandula, LiviaKrizkova, Ivan Stepanek, ZdenaDurackova. Detection of damage to DNA and antioxidative activity of yeast polysaccharides at the DNA-modified screenprinted electrode. Talanta. 2002. Volume 56.Pages 939-947,

Miroslav Pohanka and Petr Skládal. Electrochemical biosensors-principles and applications. Journal of Applied Biomedicine. 2008. Volume 6, Pages 57-64.

Mizutani F, Hirata Y, Yabuki S, Iijima S (2003) Sens.Flow injection analysis of acetic acid in food samples by using trienzyme/poly(dimethylsiloxane)-bilayer membrane-based electrode as the detector.Actuat B: Chem. Volume 91, Issues 13, Pages 195-198.

Olinda F. Canhoto and NareshMagan, 2003.Potential for detection of microorganisms and heavy metals in potable water using electronic nose technology. Biosensors and bioelectronics, Volume 5, Issue 18. Pages 751754

P. V. Sujith Kumar, Shabana Basheer,R. Ravi \& M. S. Thakur. Comparative assessment of tea quality by various analytical and sensory methods with emphasis on tea polyphenols.Journal of Food Science and Technology. 2011. Volume 48, Pages440-446.

Pena N, Tarrega R, Reviejo AJ, Pingarron JM. Automated Bioanalyzer Based on Amperometric Enzymatic Biosensors for the Determination of Ethanol in Low-Alcohol Beers. Anal Lett. 2002.Volume 35. Page 1931.

Peter Kuhnert, Patrick Boerlin, Joachim Frey. Target genes for virulence assessment of Escherichia coli isolates from water, food and the environment. FEMS Microbiology Reviews. Volume 24, Issue 1, January 2000. Pages 107 117.

Peter Ulrich, Abel ac, Thomasvon, WoedtkebBirgit Schulz c, Theodor Bergannd, Alexander Schwockc. Stability of immobilized enzymes as biosensors for continuous application in vitro and in vivo. Journal of Molecular Catalysis B: Enzymatic. 15 September 1999, Volume 7, Issues 1-4, Pages 93-100.

Petr Skládal. Advances in electrochemical immunosensors. Electroanalysis. 25 April 2005
Pollegioni L, Piubelli L, Sacchi S, Pilone MS, Molla G. 2007. Physiological functions of D-amino acid oxidases: from yeast to humans. Cell Mol Life Sci. Volume 64. Page-1373

Prodromidis MI, Karayannis MI. 2002. Enzyme Based Amperometric Biosensors for Food Analysis.Electroanalysis. volume-14. Page 241.

Prodromidis MI, Tzouwara-Karayanni SM, Karayannis MI, Vadgama P, Maines A. Amperometric determination of L-malic acid in a flow injection analysis manifold using packed-bed enzyme reactors. Analyst. 1996. Volume 121, Page 435.

Prodromidis MI, Tzouwara-Karayanni SM, Karayannis MI, Vadgama PM. Enzyme Based Amperometric Biosensors for Food Analysis. 1997. Analyst. Volume 122. Page 1101.

Rastislav Monošík, Miroslav Stred'anský, and Ernest Šturdík. Application of Electrochemical Biosensors in Clinical Diagnosis. 2012 January. Volume 26. Issue 1. Pages 22-34.

Ruchika Malhotra, Vyomesh Patel, Jose Pedro Vaqué, J. Silvio Gutkind, James F. Rusling Ultrasensitive Electrochemical Immunosensor for Oral Cancer Biomarker IL-6 Using Carbon Nanotube Forest Electrodes and Multilabel Amplification. Anal. Chem.March 1, 2010. Volume 82, Issue 8. Pages 3118-3123.

Rupesh K. Mishra ${ }^{\mathrm{ab}}$, Rocio B. Dominguez ${ }^{\mathrm{c}}$, Sunil Bhand $^{\mathrm{b}}$. Roberto Muñoz ${ }^{\mathrm{c}}$, Jean-Louis Marty. A novel automated flow-based biosensor for the determination of organophosphate pesticides in milk. Biosensors and Bioelectronics. Volume 32, Issue 1, January 1984, Pages 56-61.

S. Nishikawa, S Sakai, I Karube, T Matsunaga, S Suzuki. Dye-coupled electrode system for the rapid determination of cell populations in polluted water. Applied and environmental microbiology. April 1982. Volume 43. Pages 814-818.

S. Th. GirousiI, Ch. Gherghi, M.K. Karava. DNAmodified carbon paste electrode applied to the study of interaction between Rifampicin (RIF) and DNA in solution and at the electrode surface. Journal of Pharmaceutical and Biomedical Analysis. 19 November 2004. Volume 36, Issue 4, Pages 851-858.

S.F.D'Souza. Microbial biosensors. Biosensors and Bioelectronics.August 2001. Volume 16, Issue 6. Pages 337-353.

S.P. Mohanty, E. Kougianos. Biosensors: a tutorial review. IEEE Potentials. March-April 2006. Volume 25, Issue 2. 
Sacchi S, Pollegioni L, Pilone MS, Rossetti C (1998). Optimization of culture condition for the production of D-amino acid oxidase in a recombinant Escherichia coli.Biotechnol Tech. Volume 12. Pages 149.

Soldatkin OO, Peshkova VM, Dzyadevych SV, Soldatkin AP, Jaffrezic-Renault N, Elskaya AV.Novel sucrose three-enzyme conductometric biosensor.1 July 2008. Mater Sci EngC.Volume 28, Issues 5-6. Pages 959964.

Stephen Hearty ${ }^{\mathrm{a}}$, Joanne Brennan ${ }^{\mathrm{a}}$, Lynsey Dunne ${ }^{\mathrm{a}}$, John Quinn ${ }^{\mathrm{ab}}$, TrinadChakraborty ${ }^{\mathrm{c}}$,Paul Leonard $^{\mathrm{a}}$, Richard O'Kennedy. Advances in biosensors for detection of pathogens in food and water.Enzyme and Microbial Technology. 2 January 2003. Volume 32, Issue 1. Pages 3-13.

Surareungchai W, Worasing S, Sritongkum P, Tanticharoen M, Kirtikaral K Dual electrode signal-subtracted biosensor for simultaneous flow injection determination of sucrose and glucose.AnalChim Acta. 25 January 1999. Volume 380, Issue 1. Pages 7-15.

T Gregory Drummond, Michael G Hill and Jacqueline K Barton. Electrochemical DNA Sensors. Nature Biotechnology. 2003. volume 21, pages 1192-1199.

T. Vo-Dinh and B. Cullum. Biosensors and biochips: advances in biological and medical diagnostics. Fresenius' Journal of Analytical Chemistry. 2000. Volume 366, Pages 540-551.

Tkac J, Svitel J, Novak R, Sturdik E. Triglyceride Assay by Amperometric Microbial Biosensor: Sample Hydrolysis and Kinetic Approach. 2000. Analytical Letter 33:2441.

Tkac J, Vostiar I, Gemeiner P, Sturdik E. Application of Enzyme Biosensors in Analysis of Food and Beverages. BiosensBioelectron. 2003. Volume18. Page 1125-1129.

Tkac J, Vostiar I, Gemeiner P, Sturdik E. Stabilization of ferrocene leakage by physical retention in a cellulose acetate membrane. The fructose biosensor.Bioelectrochemistry. 2002. Volume 55. Page 149.
Tkac J, Vostiar I, Sturdik E, Gemeiner P, Mastihuba V, Annus J (2001) Bioelectrochemical Determination of Citric Acid in Real Samples Using a Fully Automated Flow Injection Manifold.Anal Chim Acta. Volume 439. Page 39.

TothillI. E.,Biosensors development and potential applications in the agricultural diagnosis sector. Computers and Electronics in Agriculture, 2001, Volume 30, Pages 205- 218.

Veerappan Mani, Balamurugan Devadas, ShenMing Chen. Direct electrochemistry of glucose oxidase at electrochemically reduced graphene oxide-multiwalled carbon nanotubes hybrid material modified electrode for glucose biosensor. Biosensors and Bioelectronics. 15 March 2013. Volume 41, Pages 309-315.

Vermeir S, Nicolaï BM, Verboven $\mathrm{P}$ et al., Microplate Differential Calorimetric Biosensor for Ascorbic Acid Analysis in Food and Pharmaceuticals. Analytical. Chemistry. 2007.Volume 79,Issue 16.Pages 6119-6127.

Wang J. Electrochemical Glucose Biosensors.Chem Rev.December 23, 2007. Volume108, Issue 2. Pages 814-825.

Wang X, Watanabe H, Uchiyama S.Amperometric 1ascorbic acid biosensors equipped with enzyme micelle membrane.Talanta. 2008. Volume 74. Page1681.

Xiaohong Chen, ChuanminRuan, JilieKong, JiaqiDeng. Characterization of the direct electron transfer and bioelectrocatalysis of horseradish peroxidase in DNA film at pyrolytic graphite electrode.Analytica Chimica Acta. 8 May 2000.Volume 412, Issues 1-2. Pages 8998.

Yang Tian, Lanqun $\mathrm{Mao}^{1}$, TakeyoshiOkajima, Takeo Ohsaka.A carbon fiber microelectrodebased third-generation biosensor for superoxide anion.Biosensors and Bioelectronics. 15 October 2005. Volume 21, Issue 4. Pages 557564.

\section{How to cite this article:}

Pavel Rout and Chaitali Chakraborty. 2020. The Commercial Application of Biosensors as an Analytical Device. Int.J.Curr.Microbiol.App.Sci. 9(05): 864-880. doi: https://doi.org/10.20546/ijcmas.2020.905.096 